\title{
Sustainable Agricultural Land Use for an Open Land Market: Prospects or Challenges?
}

\author{
Tetiana A. Vasylieva ${ }^{i}$, YeVhenita A. ZIabina ${ }^{i i}$, \\ Oleg M. OlefirenKo iii, VolodvMYr I. NesterenKo ${ }^{i v}$
}

The activities of state regulation in the field of land use have formed a number of environmental, socio-economic problems based on individual, regional and national interests. This paper summarizes the arguments and counterarguments within the scientific discussion on the issue of the impact on sustainable agricultural land use, taking into account the new legislative challenges in lifting the moratorium on the sale of agricultural land resources. This study focuses on the implementation of sustainable development goals, including goal 15 - conservation of terrestrial ecosystems and operational task 15.3 - restoration of degraded lands and soils using innovative technologies. Systematization of research in the field of sustainable land use has revealed the need for additional analysis and search for new ways to reform the land use sector, taking into account institutional and legislative changes, as well as the formation of carbon-neutral model of national economy. The purpose of the article is to identify prospects and possible threats to the development of sustainable agricultural land use in an open land market. To achieve this goal, the tools of comparative analysis were used in the work. The object of research is the land fund of Ukraine. The study period is from 2015 to 2020 . The sources of statistical information were the statistical databases of the statistical organization of the European Commission (Eurostat), the World Bank and the State Statistics Service of Ukraine. The paper presents the mechanisms of influence on effective sustainable agricultural land use, taking into account the studied statistical information and today's realities. The conducted comparative analysis of the condition of agricultural lands and systematization of normative legal acts regulating the land use industry revealed a number of potentially possible problems. To prevent negative consequences in the field of land use, the authors propose a set of measures to stabilize the sustainable development of agricultural land use.

Keywords: sustainable development, land use, land market, agriculture.

УДК 332.36

JEL Codes: Q10, Q15, R14, R52

Introduction. Land resources are considered to be the foundation of the national economy, because they form the volume of the food fund by about $90-95 \%$ and $65-70 \%$ of the consumer goods fund. Thus, the land fund of Ukraine is a strategically important resource that the state decided to protect during the country's independence by imposing a moratorium on land sales (ban on the sale and donation of land, only the possibility of renting), which has been in force since March 1992. To date, the Verkhovna Rada has adopted the Law "On Amendments to Certain Legislative Acts of Ukraine on the Conditions of Circulation of

\footnotetext{
${ }^{i}$ Tetiana A. Vasylieva, Doctor of Economics, Professor; Director of Education and Research Institute for Business, Economics and Management, Sumy State University;

${ }^{i i}$ Yevheniia A. Ziabina, specialist of the Department of Marketing, Sumy State University;

iii Oleg M. Olefirenko, Doctor of Economics, Associate Professor, Associate Professor of the Department of Marketing, Sumy State University;

${ }^{i v}$ Volodymyr I. Nesterenko, PhD student of the Department of Marketing of Sumy State University.

(C) T. A. Vasylieva, Ye. A. Ziabina, O. M. Olefirenko, V. I. Nesterenko, 2021.

https://doi.org/10.21272/mer.2021.92.05
}

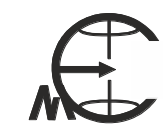


Т. А. Васильєва, С. А. Зябіна, О. М. Олефіренко, В. І. Нестеренко. Стале сільськогосподарське землекористування за умов відкритого ринку землі: перспективи чи проблеми?

Agricultural Land" [18] and signed by the President of Ukraine and from July 1, 2021 it will come into force. Accordingly, the population will have the right to sell their agricultural land (shares), agribusiness is gaining opportunities to form a stable land fund while the question remains how it will affect the further sustainable development of land use and land resources.

Analysis of recent research and publications. Problems of sustainable land use are studied by such domestic scientists as Gutorov O. [13, 14], Pashkov I. [17], Sokhnych O. [20], Khvesyk Y. [22] and others. Foreign scholars such as Alias I. [1], Dave H. [2], Kiss L. [6] and others [4] are actively studying the impact of sustainable land use on economic development. The issue of organizational and managerial aspects of sustainable agricultural land use [16] in the context of overcoming the global food crisis [3] remains open.

Sufficient scientific achievements have been formed in the direction of studying the impact of innovative development on the sphere of sustainable land use [5] and the problems of application of innovation and investment tools in the system of rational soil use [7,9].

It is necessary to pay attention to the research devoted to substantiation of expediency of development of family eco-farms as the mechanism of development of local communities in the conditions of decentralization of the power $[8,10,11,12]$.

The purpose of the paper is to study and identify possible positive and negative trends in the development of sustainable agricultural land use in an open land market in Ukraine.

Results of the research. Sustainable agricultural land use is regulated by the main criteria of the Sustainable Development Goals in Ukraine [19; 23; 24], in particular the key goal №15, namely task 15.3, which contains 6 operational indicators:

- establishment and implementation of a voluntary national task to achieve a neutral level of land degradation in the direction: "Maintenance of organic matter (humus) in soils" (organic carbon (humus) in agricultural soils (\%) - 15.3.1;

- area of arable land, thousand hectares - 15.3.2;

- share of arable land in the total territory of the country, \% - 15.3.3;

- area of land occupied under organic production, thousand hectares - 15.3.4;

- area of agricultural lands of extensive use (hayfields, pastures), thousand hectares 15.3.5;

- share of the area of agricultural lands of extensive use (hayfields, pastures), in the total territory of the country, \% - 15.3.6.

We will consider the trends of each indicator for the last five years of adherence to the policy of Sustainable Development in Ukraine in more detail.

According to indicator 15.3.1, establishment and implementation of a voluntary national task to achieve a neutral level of land degradation in the direction: "Maintenance of organic matter (humus) in soils", it is necessary to note the lack of statistical information for each year, taking into account the specifics of this indicator. Relevant statistic data are calculated once every five years based on the results of the agrochemical certification round. The data for 2015 remain relevant: in Ukraine as a whole $-3.16 \%$, Polissya $-2.33 \%$, Forest-steppe $3.21 \%$, Steppe $-3.45 \%$. The target point for 2020 to achieve sustainable development which should not be below the calculated base level is established: across Ukraine as a whole $3,14 \%$, Polissya $-2,24 \%$, Forest-steppe $-3,19 \%$, Steppe $-3,40 \%$ [15].

The dynamics of arable land area (15.3.2) and the share of land area in the country's total territory (15.3.3) are shown in Fig. 1. 
Tetiana A. Vasylieva, Yevheniia A. Ziabina, Oleg M. Olefirenko, Volodymyr I. Nesterenko. Sustainable Agricultural Land Use for an Open Land Market: Prospects or Challenges?

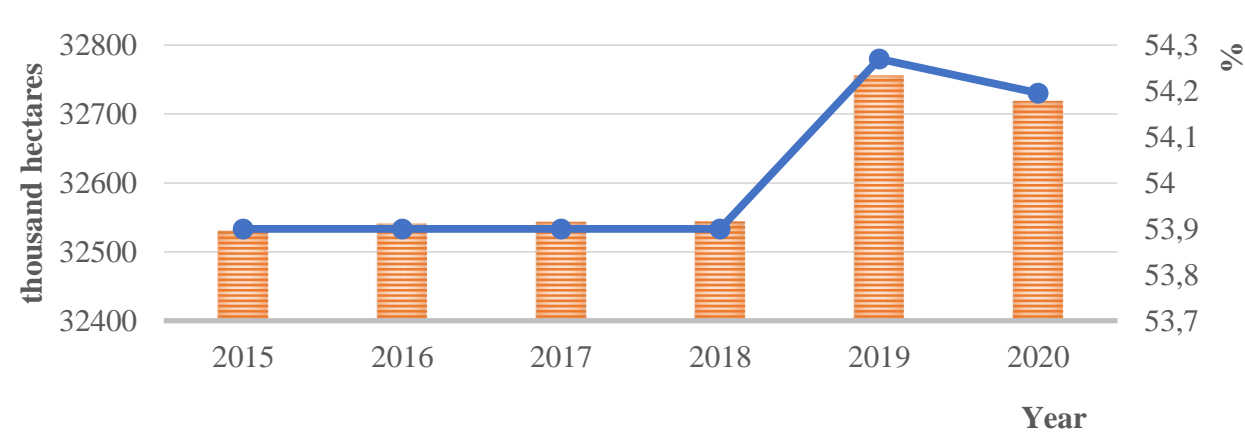

를 Area of arable land (arable land), thousand hectares

Share of arable land area in the total territory of the country, \%

Figure 1. Dynamics of arable land for 2015-2020

Source: compiled by the authors on the basis of data [15]

From fig. 1 we can note positive dynamics of increasing the arable land in the country over the past three years. At the same time, Ukraine is the third-largest in the world in terms of the arable land share in the total country' territory, followed by Moldova (54.52\%) and Bangladesh (55.39 \%). Denmark is fourth (52.59\%) and Hungary is fifth (49.58 \%).

Given the analyzed statistics, it can be concluded that Ukraine has a strong agricultural potential to effectively develop sustainable agriculture and have strong advantages on the world stage. More details in fig. 2 and fig. 3 consider the efficiency of land use.

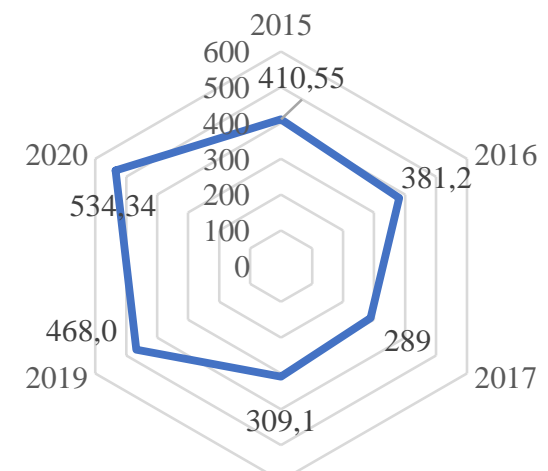

2018

Figure 2. Dynamics of the land area used for organic production, thousand hectares, 2015-2020

Source: compiled by the authors on the basis of data [15]

Figure 2 shows the changes in the area of land used for organic production over the past five years. Accordingly, it is necessary to pay attention to the fact that organic agricultural production in Ukraine is gaining momentum (in 2017 - 289 thousand hectares, in 2020 - 
Т. А. Васильєва, С. А. Зябіна, О. М. Олефіренко, В. І. Нестеренко. Стале сільськогосподарське землекористування за умов відкритого ринку землі: перспективи чи проблеми?

534.34 thousand hectares). It has a positive impact on the country's land resources (minimizes the negative effects on the environment natural environment) and allows acting as a powerful exporter in organic agricultural products. If we analyze the dynamics of change in the arable land area and the area of land used for organic production, we can note a direct correlation, because this period 2017-2020 accounts for the development of agribusiness, increasing demand for organic goods, the development of the movement eco-goods, etc. Today the above changes have suspended their development because the country needs to improve institutional, economic, environmental, regulatory and tax mechanisms for the further effective operation of agribusiness.

One should note that among the European Union countries, the leaders in the area of land occupied by organic production are Finland $(2.54 \%$ of the total utilized agricultural area), Denmark (2.3\%), Estonia (2.25\%), Italy (2.23\%), Sweden $(2.06 \%)$.

We consider the dynamics of the agricultural lands of extensive use and their share in the country' total territory in the period 2015-2020 (Fig. 3).

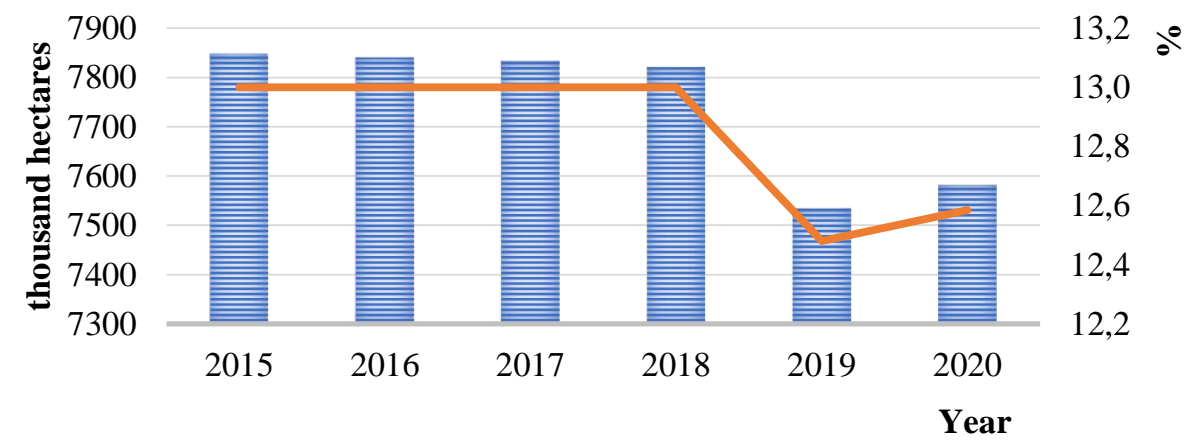

를 Area of agricultural lands of extensive use (hayfields, pastures), thousand hectares

Share of the area of agricultural lands of extensive use (hayfields, pastures), in the total territory of the country, $\%$

Figure 3. Dynamics of the agricultural lands of extensive use and their share in the total territory of the country, 2015-2020.

Source: compiled by the authors on the basis of data [15]

It is necessary to note that during 2015-2018 the area of agricultural land of extensive use and, accordingly, their share in the country's total territory almost did not change. In 2019 there was a decrease in agricultural land of extensive use by nearly 287 thousand hectares, caused by an increase in land area used for organic production, the dynamics of which is shown in Fig. 2.

One should pay attention to the significant difference between the volume of agricultural land of extensive use and the area of land used for organic production: in 2015, extensive use accounted for 7848.3 thousand hectares, and organic production only 410.55 thousand hectares, which is almost 20 times less; in 2020, 7581.11 thousand hectares accounted for extensive use, and only 534.34 thousand hectares under organic production, which is almost 14 times less. It means that we can conclude that this gap decreases, but not significantly and rather slowly. 
Tetiana A. Vasylieva, Yevheniia A. Ziabina, Oleg M. Olefirenko, Volodymyr I. Nesterenko. Sustainable Agricultural Land Use for an Open Land Market: Prospects or Challenges?

According to the above presentation of the operating goals of sustainable development 15.3.1-15.3.6, we can determine that country has not achieved the high results, and at this stage, the goal 15.3 cannot be considered at least partially fulfilled. The main reasons for this situation are, first of all, the lack of effective tools for regulating the land resources of the agro-industrial complex, the lack of channels for stimulating and controlling agribusiness, the non-functioning system of monitoring the quality of land resources, etc.

And today, all these questions remain open, but at the same time, another unknown variable is added and it is the open land market.

The adopted Law on the abolition of monitoring the sale of agricultural land divided the country into two camps, those who are against and those who are for. First of all, one should note what changes will take place from July 1, 2020, to January 1, 2024 - the opportunity to sell agricultural land no more than 100 hectares in one hand, and from January 1, 2024, the land market will open for legal entities with a limit of up to 10,000 hectares. When we consider the possibility of foreign investors and individuals of foreigners to acquire ownership of agricultural land, this issue will be put to a referendum.

The main problem that immediately arises, given the state of arable land in Ukraine, is the lack of environmental ethics of some agribusiness representatives and the use of land resources extensively. It means that changes in the form of ownership of land resources can provoke problems in the territorial organization of land use and affect the structure of sown areas and land.

Thus, if a country has made such an important decision to lift the moratorium on the sale of agricultural land, it is necessary to pay attention to the following aspects:

- first, to set reasonable limits on the structural distribution of land by extensive and intensive use, which will reduce the gaps in inefficient use of agricultural land in accordance with the operational goal of sustainable development 15.3;

- secondly, to develop tools to increase the share of organic agricultural production by reducing the tax burden or the possibility of obtaining investment subsidies for ecoagribusiness, these measures will reduce the load on the environment and allow the country to act as a powerful exporter of agricultural products;

- thirdly, to improve the regulatory framework for controlling the field of land relations [21] considering the relevant changes in the legislation of Ukraine, which will attract domestic investors to the formation of sustainable land use and implementation of European experience in decarbonizing the national economy;

- fourth, state control over the purpose of agricultural land and the creation of adequate penalties for non-compliance with legal conditions - this will form both in the business environment and among households social and environmental responsibility.

Considering these recommendations with an integrated approach, the state can turn all potential problems and threats into the line of prospects and opportunities and strengthen weaknesses in the field of sustainable land use.

Conclusions. Land resources form a system reflecting the current state of land relations and effective institutional regulation. The country will have to take several comprehensive measures to preserve the ecosystem, prevent the spread of extensive land use and strengthen territorial security to intensify work on sustainable agricultural land use in an open land market.

In the conditions of decentralization, it is necessary to stimulate local communities to form their objects of the reserve fund and ensure the rational use of natural resources for their preservation. 
The analysis of indicators of sustainable agricultural land use revealed several adverse trends. In particular, the large gap between the volume of agricultural land of extensive use and the area of land used for organic production on average more than 16-17 times exceeds the importance of agricultural land of extensive use. Also, instability in the amount of arable land and the level of degradation of land resources. Given the identified shortcomings and the slow pace of development according to the stated goals of sustainable development until 2030, some recommendations were proposed. A comprehensive approach can significantly reduce the possible negative impact of the open market of agricultural land use.

\section{References}

1. Aliyas, I. M., Ismail, E. Y. \& Alhadeedy, M. A. H. (2018). Evaluation of Applications of Sustainable Agricultural Development in Iraq. SocioEconomic Challenges, 2(2), 75-80. http://doi.org/10.21272/sec.2(2).75-80.2018

2. Dave, H. (2019). The X-ray report of "Economic growth". Financial Markets, Institutions and Risks, 3(4), 89-93. http://doi.org/10.21272/fmir.3(4).89-93.2019

3. He, Sh. (2018). Agricultural Trading System and Global Food Crisis. SocioEconomic Challenges, 4(2), 6-20. http://doi.org/10.21272/sec.2(4).6-20.2018

4. Huo, Y. \& Kristjánsson, K. (2020). An Explorative Study of Virtues in Ethical Consumption from a Confucian Perspective in an Urban-Rural-Fringe in China. Business Ethics and Leadership, 4(4), 105-122. https://doi.org/10.21272/bel.4(4).105-122.2020

5. Ivanova, E. \& Kordos, M. (2017). Competitiveness and innovation performance of regions in Slovak Republic. Marketing and Management of Innovations, 1, 145-158. http://doi.org/10.21272/mmi.2017.1-13

6. Kiss, L. B. (2020). Examination of Agricultural Income Inequality in the European Union. Business Ethics and Leadership, 4(3), 36-45. https://doi.org/10.21272/bel.4(3).36-45.2020.

7. Kucher, A., \& Kucher, L. (2017). State and problems of transfer of innovations in land use of agricultural enterprises. Marketing and Management of Innovations, 3, 435-52. http://doi.org/10.21272/mmi.2017.3-04

8. Kyrychenko, K. I., Samusevych, Y. V., Liulova, L. Y. \& Bagmet, K. (2018). Innovations in country's social development level estimation. Marketing and Management of Innovations, 2, 113-128. http://doi.org/10.21272/mmi.2018.2-10

9. Sokolov, M., Mykhailov, An. \& Khandurin, D. (2018). Distribution of investment resources: where is agriculture in the Ukraine's economy? Financial Markets, Institutions and Risks, 2(3), 38-42. http://doi.org/10.21272/fmir.2(3).38-42.2018

10. Mishenin, Y. V., Valentynov, V., Maslak, O. \& Koblianska, I. (2017). Modern transformations in small-scale agricultural commodity production in Ukraine. Marketing and Management of Innovations, 4, 358-366. http://doi.org/10.21272/mmi.2017.4-32

11. Starchenko, L. V., Samusevych, Ya. \& Demchuk, K. (2021). Social and Eco-Friendly Enterpreneurship: The Keys to Sustainability. Business Ethics and Leadership, 5(1), 118-126. https://doi.org/10.21272/bel.5(1).118-126.2021

12. Strochenko, N. I. \& Koblianska, I. I. (2016). Essential and organizational transformations of economy management in the countryside as the basis of sustainable rural development in Ukraine. Marketing and management of innovations, (3), 293-308.

13. Gutorov, O. I. (2010). Directions of formation of sustainable agricultural land use in the conditions of transformation of land relations. Approved by the Academic Council of the University (Minutes № 1 dated 02.09.2010), 28.

14. Gutorov, O. I. (2010). Problems of sustainable land use in agriculture: theory, methodology, practice.

15. State Statistics Service of Ukraine. Retrieved from http://www.ukrstat.gov.ua

16. Kovaleva, O. M. (2013). Sustainable agricultural land use: organizational and managerial aspects (Doctoral dissertation, Sumy State University).

17. Pashkov, I. A. (2009). Systemic bases of sustainable land use in Ukraine. Zaporizhia National 
Tetiana A. Vasylieva, Yevheniia A. Ziabina, Oleg M. Olefirenko, Volodymyr I. Nesterenko. Sustainable Agricultural Land Use for an Open Land Market: Prospects or Challenges?

University, 150

18. On Amendments to Certain Legislative Acts of Ukraine Concerning the Conditions of Circulation of Agricultural Lands (2020): Law of Ukraine of March 30, 2020 № 552-IX. Information of the Verkhovna Rada of Ukraine, 20, 142.

19. On the Sustainable Development Goals of Ukraine for the period up to 2030: Decree of the President of Ukraine № 722/2019. Retrieved from https://www.president.gov.ua/documents/7222019-29825

20. Sokhnich, O. A. \& Bilousov, O. M. (2011). Greening of land use. Business navigator, (5), 183-186.

21. Ukraine, Z. (2002). Land Code of Ukraine. Approved by the Resolution of the Supreme.

22. Hvesik, Yu. M. (2008). Formation of mechanisms of institutional provision of sustainable land use: foreign experience.

23. Goals of sustainable development of Ukraine, Ts. (2020). Voluntary national survey.

24. Sustainable development goals. (2017). Retrieved from https://sustainabledevelopment.un.org/sdg7

Manuscript received 30 March 2021

Mechanism of Economic Regulation, 2021, No 2, 43-50

ISSN 1726-8699 (print)

Стале сільськогосподарське землекористування за умов відкритого ринку землі: перспективи чи проблеми?

\section{$T_{\text {Етяна }}$ АнатолІївна $B_{\text {АсильєвА }}{ }^{*}$,

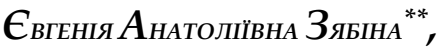 \\ $\mathrm{O}_{\text {ЛЕГ }} \mathbf{M И Х А И ̆ Л О В И ч ~}_{\text {ЛЕФІРЕНКо }}{ }^{* * *}$,

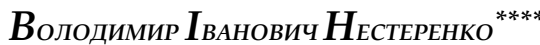

* доктор економічних наук, професор, професор кафедри фінансів і підприсмництва, директор Навчально-наукового інституту бізнесу, економіки та менеджменту

Сумського державного університету

вул. Р.-Корсакова, 2, м. Суми, 40007, Украӥна,

тел.: 00-380-542-687949, e-mail: tavasilyeva@fem.sumdu.edu.ua

** фахівець кафедри маркетингу Сумського державного університету,

вул. Р.-Корсакова, 2, м. Суми, 40007, Украӥна,

тел.: 00-380-542-687935, e-mail: e.ziabina@econ.sumdu.edu.ua

*** доктор економічних наук, дочент, дочент кафедри маркетингу

Сумського державного університету,

вул. Р.-Корсакова, 2, м. Суми, 40007, Украӥна,

тел.: 00-380-542-687935, e-mail: oleg_olefirenko@econ.sumdu.edu.ua

***** аспірант кафедри кафедри маркетингу Сумського державного університету,

вул. Р.-Корсакова, 2, м. Суми, 40007, Україна,

тел.:00-380-542-687954, e-mail:v.nesterenko@kmm.sumdu.edu.ua

Діяльність недосконалого державного регулювання в сфері землекористування сформувало ряд еколого-соціально-економічних проблем на основі індивідуальних, регіональних та загальнонаціональних інтересів. У статті узагальнено аргументи та контраргументи щодо впливу на стале сільськогосподарське землекористування враховуючи нові законодавчі виклики при скасуванні мораторію на продаж земельних ресурсів сільськогосподарського призначення. У даному дослідженні основна увага акцентується на реалізації цілей сталого розвитку, зокрема цілі 15 - збереження екосистем суші та оперативному завданні 15.3 - відновлення деградованих земель та грунтів з використанням інноваційних технологій. Систематизація наукових досліджень 
Т. А. Васильсва, С. А. Зябіна, О. М. Олефіренко, В. І. Нестеренко. Стале сільськогосподарське землекористування за умов відкритого ринку землі: перспективи чи проблеми?

в сфері сталого землекористування виявила необхідність в додатковому аналізі та пошуку нових шляхів реформування галузі землекористування враховуючі інституційні та законодавчі зміни, а також формування вуглецево-нейтральної моделі розвитку національної економіки. Метою статті $\epsilon$ виявлення перспектив та можливих загроз в розвитку сталого сільськогосподарського землекористування в умовах відкритого функціонування ринку землі. Для досягнення поставленої мети у роботі було застосовано інструментарій компаративного аналізу. Об'єктом дослідження є земельний фонд України. Період дослідження з 2015 року по 2020 рік. Джерелами статистичної інформації стали статистичні бази даних статистичної організації Європейської Комісії (Свростат), Світового банку та Державної служби статистики України. У роботі представлені механізми впливу на ефективне стале сільськогосподарське землекористування 3 урахуванням досліджуваної статистичної інформації та сьогоднішніх реалій. Проведений компаративний аналіз стану земель сільськогосподарського призначення та систематизація нормативно-правових актів які регулюють галузь землекористування виявив ряд потенційно можливих проблем. Для запобігання негативних наслідків в сфері землекористування, авторами запропоновано комплекс заходів за для стабілізування сталого розвитку сільськогосподарського землекористування.

Ключові слова: сталий розвиток, землекористування, ринок землі, сільське господарство.

JEL Codes: Q10, Q15, R14, R52

Figure: 3; References: 24

Language of the article: English 